\title{
EXPANSÃO CANAVIEIRA E IMPACTOS SÓCIO-ESPACIAIS DA PRODUÇÃO DE AGROCOMBUSTÍVEL NO TRIÂNGULO MINEIRO (1980-2012)
}

\author{
EXPANSIÓN DE LA CAÑA Y IMPACTO SOCIO-ESPACIAL DE LA \\ PRODUCCIÓN DEL AGROCOMBUSTIBLES EN EL TRIÁNGULO MINEIRO
}

(1980-2012)

\section{SUGARCANE EXPANSION AND SOCIO-SPATIAL IMPACTS OF AGROFUEL PRODUCTION ON TRIANGULO MINEIRO (1980-2012)}

\author{
Natália Lorena Campos \\ Mestranda em Geografia - UFU \\ natizinhacampos@yahoo.com.br \\ João Cleps Junior \\ Professor do Instituto de Geografia - UFU \\ Jcleps@ufu.br
}

Resumo: O tema da pesquisa envolve a produção de agrocombustíveis e a expansão da produção canavieira na região do Triângulo Mineiro/Alto Paranaíba, que é uma das principais discussões da questão agrária atual, a partir do agravamento de problemas no campo, como a incorporação de terras para a monocultura canavieira. Como principais objetivos do trabalho, buscamos compreender as dimensões socioterritoriais da expansão da produção canavieira recente para a produção de agrocombustíveis no espaço agrário de Minas Gerais e suas relações com as estruturas sociais rurais (principalmente a produção camponesa/familiar); analisar o desenvolvimento da agroindústria canavieira frente as demais produções agrícolas e pecuária da região e verificar os principais impactos da expansão dessa monocultura. Com isso, foi realizado uma revisão bibliográfica da temática afim e levantamento de dados e informações em fontes secundárias. Nesse sentido, temos a apropriação dos territórios para a produção canavieira como a principal causa dos conflitos e disputas territoriais no campo brasileiro, onde a industrialização da agricultura subordina a natureza ao capital.

Palavras-chave: Agrocombustíveis. Agroindústria canavieira. Cana-de-açúcar. Produção camponesa/familiar. Triângulo Mineiro/Alto Paranaíba.

Resumen: El tema de la investigación consiste en la producción de biocombustibles y la expansión de la producción de la caña de azúcar en el Triángulo Mineiro / Alto Paranaiba, que es un de los principales debates actuales de la cuestión agraria, de la agravación de los problemas en el campo, como la incorporación de la tierra para el monocultivo de la caña de azúcar. Los principales objetivos de este estudio, hemos tratado de comprender las dimensiones socio-territoriales de la reciente expansión de la producción de caña de azúcar para la producción de biocombustibles en el espacio agrario de Minas Gerais y sus relaciones con las estructuras sociales rurales (sobre todo la producción campesina / familiar), para analizar el desarrollo de la agroindustria frente a los cultivos de caña de azúcar y otros ganaderos de la región y evaluar los principales impactos de la expansión del monocultivo. Con esto, una revisión de la literatura se llevó a cabo del tema y la recopilación de datos relacionados y la información de fuentes secundarias. En este sentido, tenemos la propiedad de los territorios para la 
producción de caña de azúcar como la principal causa de conflictos y disputas territoriales en zonas rurales de Brasil, donde la industrialización de la agricultura hace la naturaleza subordinada al capital.

Palabras-clave: Agrocombustibles. Industria de la caña de azúcar. Caña de azúcar. Producción campesina/familiar. Triángulo Mineiro/Alto Paranaiba.

Abstract: The research theme involves the biofuels production and the sugarcane production expansion on Triangulo Mineiro/High Paranaiba, which is a main discussions of the current agrarian question, from the problems field aggravation, as land incorporation to sugarcane monoculture. The main study objectives, we sought to understand the sugarcane production recente socio-territorial dimensions to biofuels production on agrarian space of Minas Gerais and their relationships with rural social structures (peasant/familiar production mainly); analyze sugarcane industry development front of the other agricultural production and livestock on region and check major impacts of monoculture expansion. Thus, was carried out a theme literature review and data and information collection in secondary sources. Accordingly, have territories ownership to sugarcane production as the principal cause of territorial conflicts and disputes on brazilian field, where agriculture industrialization subordinates the natural to capital.

Keywords: Agrofuels. Sugarcane industry. Sugarcane. Peasant/family production. Triangulo Mineiro/High Paranaiba.

\section{Introdução}

O tema principal deste trabalho envolve a produção de agrocombustíveis, mais precisamente a expansão da produção canavieira na região do Triângulo Mineiro/Alto Paranaíba em Minas Gerais, que é uma das principais discussões da questão agrária atual, a partir do agravamento de problemas como a escassez dos combustíveis fósseis, em particular do petróleo. Devido às crises ocorridas no setor sucroenergético, o Estado passou a incentivar a produção do etanol como combustível alternativo em substituição ao petróleo, que se tornara uma opção cara no cenário mundial. Foi a partir da década de 1970 e com o Primeiro choque do petróleo (1973), que o governo brasileiro passou a incentivar essa produção, com a criação do Programa Nacional do Álcool - Proálcool, em 1974. O Proálcool teve como objetivo estimular a produção do álcool com a finalidade de atender as necessidades do mercado interno e externo e a política de combustíveis automotivos.

Frente às crises do petróleo houve um incentivo à instalação e manutenção de destilarias e novas usinas de cana-de-açúcar em todo país, principalmente no estado de São Paulo, onde o município de Ribeirão Preto e seu entorno se destaca na produção do 
álcool combustível. Recentemente, nesse processo, Minas Gerais registra um aumento significativo na implantação de usinas, que teve início a partir da década de $1980 \mathrm{em}$ diversas regiões do estado. Foi a partir da década de 1990 e, principalmente, durante a década de 2000 que o número de usinas aumentou vertiginosamente, passando de 7 para 59 unidades, sendo destas 47 já instaladas e 12 projetadas. A mesorregião do Triângulo Mineiro/Alto Paranaíba concentra 35 das unidades instaladas e projetadas em Minas Gerais.

A partir dessas questões, o objetivo central do trabalho é compreender as dimensões socioterritoriais da expansão da produção canavieira recente para a produção de agrocombustíveis no espaço agrário de Minas Gerais e suas relações com as estruturas sociais rurais (principalmente a produção camponesa/familiar), analisar o desenvolvimento da agroindústria canavieira em Minas Gerais, na mesorregião do Triângulo Mineiro/Alto Paranaíba assim como seus aspectos frente as demais produções agrícolas e pecuária da região, a fim de verificar os principais impactos da expansão dessa monocultura ao pequeno produtor rural, aos assentados da Reforma Agrária e as discussões levantadas a respeito do crescimento da monocultura canavieira, que ocupam extensas áreas que poderiam ser utilizadas para a produção de alimentos básicos.

No intuito da realização desse estudo e para a obtenção dos objetivos pretendidos, foi realizada num primeiro momento uma revisão bibliográfica acerca de alguns teóricos estudiosos da temática e consulta em fontes qualitativas como relatórios e jornais para melhor compreensão das temáticas do agronegócio, das disputas territoriais, conflitos, o setor sucroenergético a fim de compreender sua expansão em áreas de cerrado (o caso da mesorregião do Triângulo Mineiro/Alto Paranaíba - área de estudo da pesquisa), a questão agrária existente - o agronegócio versus agricultura camponesa/familiar - nesse ponto destacamos os embates entre essas duas frentes de produção assim como as disputas territoriais que marcam o processo de produção agrícola atual.

Foram consultadas fontes do IBGE na coleta dos dados da Produção Agrícola Municipal - PAM no Sistema IBGE de Recuperação Automática - SIDRA. Os dados coletados refere-se a área plantada de cana-de-açúcar em todos os municípios do Triângulo Mineiro/Alto Paranaíba a fim de mapeá-las trazendo sua evolução. Em relação à dinâmica do setor sucroenergético, foram consultados sítios da União dos Produtores de Bioenergia - UDOP onde foram contabilizadas as usinas projetadas e 
instaladas em Minas Gerais e a União da Indústria de Cana-de-açúcar - ÚNICA, responsável pela coleta de informações do setor, além de permitir o mapeamento dessas unidades. O Sindicato da Indústria de Fabricação do Álcool no Estado de Minas Gerais - SIAMIG teve grande contribuição em relação ao desenvolvimento do setor. Nesse trabalho, buscamos uma caracterização do setor canavieiro em Minas Gerais a partir da coleta de dados e informações a respeito do desenvolvimento da produção sucroenergética e as implicações nos embates da questão agrária atual.

Como justificativa do trabalho, temos a importância da análise dos impactos que a monocultura canavieira tem gerado no território mineiro, na produção camponesa/familiar (território campesino), que enfrenta constantes disputas e embates contra o agronegócio. Os impactos discutidos nesse trabalho vão além da preocupação da ameaça à agricultura. A questão do trabalho e do trabalhador também faz parte da problemática da produção de agrocombustíveis, por ser um trabalho degradante e precarizado. A sujeição dos trabalhadores nas lavouras canavieiras acarreta o processo migratório que muitas vezes alteram a dinâmica local, onde alguns municípios não estão preparados infraestruturalmente para alojarem essa mão-de-obra temporária, além de dificilmente oferecer condições de saúde, alimentação, higiene, que são necessidades básicas da população. Esse fator só é vantajoso para os empresários do setor e para a acumulação capitalista.

São problemas como esses, principalmente de ordem social que preocupam e desperta a necessidade de compreensão da expansão canavieira desenfreada em Minas Gerais, sobretudo no Triângulo Mineiro/Alto Paranaíba. O embate entre a agricultura camponesa e o agronegócio é um dos principais problemas estruturais do modelo capitalista em relação ao campo.

\section{Breves considerações sobre a produção canavieira no Brasil}

A produção canavieira foi uma das primeiras atividades produtivas e econômicas no Brasil desde o início da colonização que se deu no século XVI e ainda hoje se configura como uma atividade de grande importância no cenário econômico nacional, tanto na produção de açúcar, etanol e energia. O Brasil é o país que possui a maior produção de cana-de-açúcar no mundo. Seu início ocorreu na Zona da Mata Nordestina voltada à produção de açúcar que era o principal produto de exportação nos séculos XVI 
e XVII (período colonial e primeiras décadas da fase republicana) durante o período "ciclo" do açúcar. Além do ciclo do açúcar, o Brasil passou por outros períodos econômicos como o do ouro (final do século XVII), do café (1830 a 1930) e da borracha (primeira fase: 1879 - segunda fase: 1942), que movimentaram a economia do país durante seus auges. No início da economia do açúcar, a força de trabalho era primeiramente escrava, passando a assalariada somente próximo ao fim da escravatura no Brasil.

Com isso, o país passou a receber mão de obra principalmente da Europa em sua ocupação humana e econômica a fim de abastecer o mercado europeu. Segundo Furtado (1963), a ocupação econômica das terras americanas constitui um episódio da expansão comercial da Europa, onde a busca por matérias primas de exportação garantia a soberania econômica dos países europeus. O açúcar era o produto econômico mais cobiçado da época. É o que Furtado (1963) classificou como "empresa colonial agrícola européia". "A experiência na produção açucareira e solução dos problemas técnicos relacionados à produção fez com que a indústria portuguesa se desenvolvesse para os engenhos açucareiros" (FURTADO, 1963, p. 10).

Com o processo de produção de açúcar, o país obteve um desenvolvimento técnico da produção, que fez com que outros ramos industriais se desenvolvessem. A produção de açúcar no Brasil, assim como posteriormente a de etanol passou por momentos de auge e declínio ao longo dos anos. Em 1875 a produção açucareira entra em declínio, uma vez que a Europa passou a produzir açúcar a partir da beterraba, tornando-se independente da importação do açúcar. O desenvolvimento da cafeicultura também foi responsável pelo declínio da cultura canavieira. O cultivo da cana-de-açúcar retomou com a crise da cafeicultura, onde houve o incentivo para a produção de cachaça e uso da cultura para alimentação animal (gado leiteiro).

Como forma de solucionar o declínio da produção e a má qualidade do açúcar, o Estado passou a incentivar a criação dos engenhos centrais a partir do processo de modernização das lavouras, que se estendeu de 1870 a 1930 conforme aponta Ramos (1991). A formação dos engenhos centrais não obteve o êxito esperado. Os senhores de engenho deveriam investir em melhorias das condições dos canaviais com o apoio do Estado, o que melhoraria a produtividade. Houve investimentos para a instalação de novas unidades que foram criadas a partir da abertura ao capital estrangeiro na implantação de unidades centrais no país. O fracasso deu-se a partir de um conflito entre 
agricultores (senhores de engenho) e capital industrial (usineiros). Os senhores de engenho não aceitaram a perda de controle sobre a totalidade do processo produtivo do açúcar, que era a base do poder político e econômico.

A nova forma de organização da produção impunha aos senhores de engenho uma perda de poder: eles deveriam ficar subordinados ao capital industrial estrangeiro e passariam a receber apenas a parcela relativa à matéria-prima, e esta poderia ser rebaixada pelos donos dos Engenhos Centrais (VIAN, 2003, p. 66).

Foi no final da década de 1920 e início da década de 1930 que a produção açucareira migrou do Nordeste do país para o Centro-Sul, mais precisamente São Paulo e Rio de Janeiro. Segundo Bray, Ferreira e Ruas (2000) como forma de retomar a primazia da produção canavieira, o Nordeste intensificou o cultivo da cana e os usineiros passaram a investir melhorando as fábricas e construindo novas usinas, enquanto o governo paulista se empenhava no combate às moléstias da cana, classificada pelos autores como mosaico, uma doença que atingiu e devastou os canaviais paulistas, fazendo com que importassem novas variedades de cana japonesas.

[...] os proprietários de engenhos aceitaram a modernização, desde que eles fossem os donos dos engenhos centrais e que recebessem os mesmos incentivos que eram dados ao capital estrangeiro na fracassada primeira fase do processo. Assim, a manutenção da integração vertical para trás, que caracteriza o setor até os dias de hoje, e pelo acesso a créditos subsidiados pelo Estado (VIAN, 2003, p. 67).

Durante os anos 1930 houve uma preocupação pelo governo em criar políticas públicas como forma de "proteção" ao setor, tais como implantação de fábricas, aquisição de terras, plantio das lavouras e obras de infraestrutura necessárias. Em agosto de 1931 o Ministério da Agricultura criou a Comissão de Estudos sobre o Álcool Motor - CEAM já pensando na possibilidade de sua utilização como combustível. No mesmo ano o governo federal criou a Comissão de Defesa da Produção do Açúcar, com o objetivo de estudar e incentivar a produção de álcool anidro para misturar à gasolina com vistas à diminuição do excedente de açúcar e para diminuir a importação de derivados de petróleo.

A CEAM foi a primeira intervenção estatal para o setor canavieiro. Como desdobramento da Comissão de Defesa da Produção do Açúcar - CPDA e da CEAM, o governo federal criou em 1933 o Instituto do Açúcar e do Álcool - IAA, com o objetivo de dirigir, intervir, fomentar e controlar a produção de açúcar e álcool do país (BRAY; 
FERREIRA; RUAS, 2000, p. 14), que se estendeu até a década de 1970. O objetivo principal do IAA era "regular o mercado de açúcar via usos alternativos para a cana e para os subprodutos de seu processamento industrial, incorporando funções de fomento à diversificação das usinas, obrigando-as a destinar parte da matéria-prima à produção de anidro" (VIAN, 2003, p. 74).

O IAA controlava a produção de açúcar através das cotas. Inicialmente eram baseadas na capacidade instalada de cada unidade produtiva e nas previsões de crescimento do mercado. A instalação de novas unidades e a expansão das já existentes devia ser previamente autorizada pelo IAA. Mas essa obrigatoriedade não era respeitada não era respeitada pelos grandes grupos do setor, principalmente os paulistas (VIAN, 2003, p. 76).

No contexto da Segunda Guerra Mundial (1939-1945), houve incentivos à produção de álcool combustível devido à dificuldade de exportação do açúcar e racionamento da gasolina. $\mathrm{O}$ incentivo à produção de álcool pelas destilarias fez com que o governo federal criasse mais uma política pública, o Plano de Desenvolvimento do Álcool:

No ano de 1942, o IAA passou a adotar várias medidas que resultaram num verdadeiro "plano de economia de guerra". A produção de açúcar de usina que ultrapasse o limite de 15.200 .000 sacos de $60 \mathrm{~kg}$ deveria ser entregue ao IAA para ser transformada em álcool. Neste contexto, o IAA passou a comercializar todo o tipo de álcool fabricado no país e criou o Plano de Desenvolvimento do Álcool. Esse Plano garantia o crescimento da produção do álcool anidro e o abastecimento do álcool hidratado no país (BRAY; FERREIRA; RUAS, 2000, p. 20).

Durante a Segunda Guerra Mundial, houve uma escassez dos derivados de petróleo e uma valorização da produção do álcool. Nesse período, destacou-se a expansão da agroindústria canavieira em Piracicaba, interior de São Paulo, com a criação da primeira fábrica brasileira de equipamentos para atender a produção de açúcar.

A década de 1950 foi marcada pela expansão da agroindústria canavieira, sobretudo em São Paulo, ocupando terras anteriormente destinadas ao cultivo do café, mantendo a estrutura fundiária vigente e, aos poucos, reforçando sua concentração. A partir desta década, o estado de São Paulo tornou-se o maior produtor de açúcar do país e, pela primeira vez desde o período colonial, Pernambuco perdeu a sua primazia. (SANTOS, 2009, p. 110). 
Ainda nesse contexto, as usinas paulistas foram incentivadas a ampliar sua produção de açúcar e álcool para abastecer o mercado interno e possuíam melhores condições que as usinas nordestinas para atender a demanda de açúcar, principalmente no Centro-Sul.

Com a modernização da agricultura após a década de 1960, houve um movimento expansionista caracterizado pelo expressivo crescimento econômico e pelo grande avanço tecnológico. Como aponta Hespanhol (2008), a partir da década de 1950, a Revolução Verde derivou diretamente do modelo de desenvolvimento produtivista predominante até o final dos anos 1970 o que fez com que a produção e produtividade agrícola se expandissem significativamente.

Apesar do aparente sucesso da modernização da agricultura, o passivo ambiental dela decorrente é muito grande. A expansão de monoculturas e o uso indiscriminado de máquinas, implementos, fertilizantes químicos e de biocidas comprometeram a qualidade ambiental de vastas áreas dos países desenvolvidos e subdesenvolvidos (HESPANHOL, 2008, p. 372).

O processo expansionista da agricultura e as monoculturas fizeram surgir questões sobre os problemas ambientais e sanitários surgidos, além de que "a agricultura moderna também não levou a superação do problema da fome no planeta, apesar de ter havido a ampliação da oferta de alimentos, os problemas relacionados à sua distribuição perduraram e até se agravaram" (HESPANHOL, 2008). Do ponto de vista ambiental, o incremento da produção de alimentos, fibras e agrocombustíveis para fazer frente à demanda internacional está sendo realizado com base neste modelo de desenvolvimento de forma insustentável, o que abre brecha para críticas de ambientalistas a esse modo de produção, com alto avanço tecnológico.

Foi nesse contexto de modernização da agricultura, territorialização do capital e ajustes neoliberais, que surgiu o agronegócio. A partir do discurso dos setores dominantes da sociedade, o agronegócio se constitui no mais importante caminho para a agricultura brasileira, tornando-se paradigmático (FABRINI, 2010, p. 60).

Essa modernização da agricultura representa a modernização capitalista no movimento constante de auto-expansão e reprodução do capital. "Esse processo gerou fortes impactos ao mundo do trabalho rural como a destruição de formas tradicionais de produção e desterritorialização do camponês - expropriação de uma parcela da população rural" (GOMES; CLEPS JUNIOR, 2006, p. 135). 


\section{As crises do Petróleo e a dinâmica agroindustrial a partir da década de $\mathbf{1 9 7 0}$}

Durante a década de 1970, com a crise no mercado mundial de açúcar e devido à pressão a respeito da necessidade de preservação dos recursos naturais e a escassez de petróleo (Primeiro choque do petróleo), surgiu à preocupação mundial em relação à forma de produção e consumo de uma nova fonte de energia. Com isso, tem-se o intento dos combustíveis alternativos, menos prejudicial ao meio ambiente e que suprisse a necessidade mundial, podendo ser uma alternativa de substituição da matriz energética do país.

Embora o etanol como combustível seja considerado uma fonte de energia limpa, menos prejudicial ao meio ambiente, o seu modo de produção traz inúmeras implicações em relação às questões ambientais além de expulsar os trabalhadores do campo e ameaçar a produção de alimentos. Segundo Fabrini (2010), o processo de modernização da agricultura e a incorporação de novas terras à dinâmica capitalista provocaram a expulsão de milhares de pequenos proprietários, rendeiros, ribeirinhos, caiçaras, posseiros, quilombolas, dentre outros camponeses, e indígenas de suas terras.

Mesmo levantando questões que implicam na contestação do modelo agroindustrial, a demanda por combustíveis cresceu vertiginosamente, sobretudo, os alternativos devido às crises que ocorreram durante a década de 1970 em relação ao petróleo. Como forma de incentivar o setor, o IAA junto ao governo federal criou o Programa Nacional de Melhoramento da Cana-de-açúcar - PLANALSUCAR para renovar as variedades de cana produzidas no país. Nesse sentido, a importância da relação indústria e agricultura permitiram o sucesso da produção do etanol graças aos subsídios creditícios e incentivos fiscais.

O processo de integração indústria e agricultura não se deu à margem das relações entre as grandes empresas, os grupos econômicos e o Estado. Este último atuou, sobretudo, através de subsídios creditícios, incentivos fiscais e toda uma bateria de políticas incentivadoras das exportações (MÜLLER, 1989, p. 18).

Essa integração indústria-agricultura foi denominada por Müller (1989) de complexo agroindustrial, no qual a produção agrária não se dá apenas na dependência das solicitações do comércio, mas também de um conjunto de indústrias que tem nas atividades agrárias seus mercados. Para Müller, o complexo agroindustrial 
[...] é uma forma de unificação das relações interdepartamentais com os ciclos econômicos e as esferas da produção, distribuição e consumo, relações essas associadas ás atividades agrárias. Vale dizer que o complexo agroindustrial é considerado como uma unidade analítica da acumulação de capital no país (MÜLLER, 1989, p. 23).

Foi nos anos de 1970 e a partir dos desdobramentos economicamente positivos da união entre indústria e agricultura que o governo brasileiro criou o Programa Nacional do Álcool - PROÁLCOOL (1975 a 1985) como forma de aumentar a produção de etanol e incentivar o seu uso. O etanol (ou álcool etílico) é produzido em usinas a partir de matérias-primas como cana-de-açúcar, milho ou beterraba. No Brasil a produção se dá pela cana-de-açúcar por ser mais rentável e fácil de produzir, onde é produzido o álcool anidro e o hidratado. O anidro é utilizado como aditivo em combustíveis, composto por $99,5 \%$ de álcool puro e $0,5 \%$ de água. Sua concentração na gasolina é de $25 \%$ de acordo com a EMBRAPA. O hidratado é utilizado como combustível composto por $96 \%$ de álcool puro e 4\% de água, utilizado no Brasil desde 1979 (EMBRAPA, 2011).

O etanol é um agrocombustível, ou seja, um combustível renovável, que não precisa de materiais de origem fóssil, como o petróleo e pode ser usado na fabricação de bebidas como para combustível, o que é feito no Brasil. Essa preferência é pelo fato de o etanol produzir $89 \%$ menos de $\mathrm{CO}_{2}$ que a gasolina. Além disso, o etanol brasileiro é considerado um etanol avançado por alcançar as normas de emissão de $\mathrm{CO}_{2}$ definidas pelo Protocolo de Kyoto.

\section{Principais fases do Programa Nacional do Álcool - PROÁLCOOL}

O Proálcool foi um programa classificado como bem-sucedido oficialmente implantado no governo Geisel, em 1975, sob período da ditadura militar, com o objetivo de estimular a produção de álcool em substituição a gasolina, derivada do petróleo e que estava passando por grave crise econômica, por ser um combustível não-renovável, podendo esgotar-se. Sua primeira fase corresponde de 1975 a 1979 onde surgiram os primeiros automóveis movidos exclusivamente a álcool. Nessa fase o governo brasileiro investiu fortemente nas destilarias anexas, havendo um crescimento na produção de álcool anidro para ser misturado à gasolina. Nessa fase do Proálcool o número de 
destilarias autônomas e anexas aumentou juntamente com a produção de álcool, o que objetivou dinamizar o Proálcool. O IAA incentivou a produção de álcool anidro "estipulando o preço de paridade em 44 litros de álcool por saca de 60 quilos de açúcar, o que fazia com que fosse indiferente para a usina produzir um ou outro produto". Foram criadas linhas de crédito subsidiado e garantias de compra do produto (VIAN, 2003, p. 87).

Sua segunda fase corresponde ao período do Segundo choque do petróleo (1979), mais significativo em relação ao seu impacto negativo à economia mundial. Nesse período houve uma maior necessidade na produção de álcool combustível com foco maior para a produção do hidratado. Como políticas para o setor foram criados o Conselho Nacional do Álcool - CNAL e a Comissão Executiva Nacional do Álcool CENAL como organismos para agilizar o Proálcool. Os créditos de subsídios continuaram e foi estipulada uma produção de $60 \mathrm{mil}$ litros/dia para as destilarias continuarem recebendo os subsídios.

A opção pela produção do álcool em destilarias possui um custo menor do que nas usinas (cerca de 20\%) de acordo com Alcântara Filho e Silva (1981). Foi em sua segunda fase que o programa deslanchou e obteve sucesso com a crescente produção de álcool. Nessa fase, o incentivo era à implantação de destilarias autônomas e a produção de álcool era mais rentável em relação à de açúcar. Houve um crescimento de unidades instaladas no Oeste e Nordeste de São Paulo, em Goiás e no Triângulo Mineiro/Alto Paranaíba. "Entre 1981 e 1985 foram implantadas novas destilarias, principalmente em regiões que eram marcadas pela presença de latifúndios com pecuária extensiva de corte no estado de São Paulo" (VEIGA FILHO; RAMOS, 2006, p. 50).

As usinas tradicionais tinham mais de 50 anos no negócio e os novos empresários atingiram maiores índices de produção e produtividade. Houve ainda incentivo por parte dos Governos Federal e Estadual a compra de carros movidos a álcool, reduzindo o IPI, além da isenção de impostos e taxas para taxistas que optassem pelo uso de carros a álcool.

Em sua fase de estagnação (de 1985 a 1995) o Brasil passou a produzir e vender um grande número de automóveis movidos a álcool, alcançando uma marca de 95,8\% de toda a frota vendida. No mesmo período, o preço do barril de petróleo cai (“contrachoque do petróleo"), fazendo com que os consumidores voltassem ao uso da gasolina, o que coincide com um período de escassez de recursos públicos no Brasil 
para subsidiar a produção do etanol. Houve uma queda nos índices de produção de etanol e corte dos subsídios, o que chamamos de desregulamentação do setor, devido aos baixos preços pagos aos produtores, o que não relaciona com a demanda pelo combustível por parte dos consumidores, que ainda era estimulada e subsidiada pelo governo. Vale ressaltar que a ausência de recursos se dava apenas ao setor sendo que o uso do álcool combustível ainda era incentivado pelo governo.

Vian (2003) aponta a desregulamentação do complexo e as tentativas posteriores de auto-regulação que culminaram com a consolidação da União da Agroindústria Canavieira de São Paulo - UNICA como entidade de representação dos interesses desse estado, como principal fato ocorrido na década de 1990. Nesse período surgiram algumas restrições novas no complexo.

Com medidas de cunho liberalizante, o Estado iniciou a década de 1990, se retirando, gradativamente, do centro das decisões acerca do setor, deixando-o nas mãos da iniciativa privada. Essa retirada do governo do controle das atividades do setor alcooleiro foi o que caracterizou seu processo de desregulamentação, ou seja, processo no qual o Estado deixou de regulamentar a produção, estoque, comercialização e preços do setor (PEREIRA, 2007, p. 59).

Durante sua fase de estagnação, houve uma redução da participação do governo nas decisões do setor. Isso fez com que ocorressem mudanças na forma de comercialização e no estabelecimento dos preços do álcool, além da perda da credibilidade dos carros movidos a álcool e no consumo do produto. A estagnação do setor foi conseqüência da ausência de políticas públicas especificas para o setor.

Durante o governo Collor, em 1990, o IAA foi extinto. A extinção do IAA foi a primeira medida de desregulamentação promovida pelo Estado que envolvia o setor, e mais tarde a liberalização dos preços dos seus produtos. Houve uma estabilidade da produção e descrédito do setor devido a falta do álcool, o que fez com que muitas usinas quebrassem e outras mudassem o foco de produção para o açúcar. Ainda em 1990, foi eliminado o privilégio concedido pelo governo de redução do IPI para automóveis movidos a álcool e a frota desses veículos diminuiu.

No entanto, o governo brasileiro ainda acreditava na eficiência do álcool como combustível e com isso passou a estimular sua produção a partir da medida provisória $\mathrm{n}^{\mathrm{o}}$ 1.662 de 28 de maio de 1998 onde o percentual de adição de álcool anidro a gasolina tornasse obrigatório de 22 até $24 \%$, e como forma de utilização do álcool combustível 
os preços do etanol e da gasolina foram equiparados. Foi nesse período que houve a inserção do capital estrangeiro.

Com a extinção do IAA, o controle e o planejamento do setor ficaram a cargo da Secretaria de Desenvolvimento Regional da Presidência da República e, posteriormente, com o Conselho Interministerial do Álcool - CIMA, presidido pelo Ministério da Indústria e do Comércio até 1999, quando passou para o Ministério da Agricultura. A indefinição quanto ao órgão responsável pela regulamentação do setor foi uma das causas da lentidão quanto à adoção de novas regras de gestão e de políticas específicas para o álcool (VIAN, 2003, p. 101).

A crise na produção do álcool combustível afetou a credibilidade do Proálcool, que entrou numa fase de redefinição (1995 a 2000). A quantidade de cana-de-açúcar produzida no Brasil manteve estável entre 2 e 3 milhões de toneladas. Um fator que condicionou no processo de desregulamentação do setor foi a ausência da intervenção estatal, no qual algumas empresas não conseguiram se adaptar ao livre mercado, quebrando.

Nos anos recentes vivenciamos uma nova expansão da monocultura canavieira no país. Após a fase de desregulamentação e reestruturação do setor na década de 1990, a dinâmica do complexo canavieiro passou a uma organização setorial em campos organizacionais. As empresas investiram em maior produtividade e menores custos de produção. Nesse sentido, houve o surgimento de novos produtos, novos segmentos de mercado para os já existentes, e novas técnicas de produção, que fez com que a estrutura do setor alterasse para uma estrutura heterogênea.

Os interesses comuns ao complexo canavieiro, como o papel do álcool como combustível líquido, tributação, meio ambiente, co-geração de energia e abertura de mercados externos, permitiram sua estabilidade atual.

[...] o complexo fragmenta-se pelo lado técnico e produtivo e torna-se coeso pelo lado institucional, algo nunca visto anteriormente no Brasil. As disputas pelo acesso privilegiado ao Estado e às entidades de representação foram substituídas pelas ações conjuntas e coordenadas no âmbito institucional. Mas ainda persistem algumas disputas regionais que precisam ser resolvidas para que não voltem a causar crises sistêmicas (VIAN, 2003, p. 132).

A fragmentação do complexo agroindustrial em campos organizacionais foi marcada pelo retorno do capital estrangeiro adquirindo empresas e formalizando parcerias, visando à produção e a comercialização do açúcar. Durante a implementação 
do Proálcool, o objetivo da intervenção estatal era o de equilibrar os mercados evitando o desabastecimento e as variações bruscas de preços. Na fase pós-desregulamentação, o que predomina é a concorrência empresarial na busca de inovações tecnológicas e na produção em terras de boa qualidade. Isso se deve aos custos mais baixos e lucro acima da média.

Temos nessa fase o investimento por parte das empresas, direcionados à especialização da produção através do uso dos subprodutos da cana, o que não ocorria nos anos 1980, onde os investimentos se limitavam em melhores condições técnicas para seus equipamentos. Vian (2003) aponta como possibilidades de melhor aproveitamento das economias de diversificação produtiva, a co-geração de energia, que só deslanchou com a crise energética. A produção de energia pelas usinas já é uma realidade comum em muitas empresas do Centro-Sul. Muitas empresas mineiras já inseriram a produção de energia em seu processo produtivo e a utiliza para autosustentação e ainda vendem o excedente.

Nos anos 2000, durante o segundo mandato do governo Fernando Henrique Cardoso (1998-2002) surgiram os automóveis bicombustíveis - movidos a álcool e/ou gasolina, os chamados carros flexfuel. Com isso, os investimentos no setor foram retomados e o plantio da cana-de-açúcar para a produção do etanol avançou além das áreas tradicionais (interior paulista e Nordeste), alcançando os cerrados.

Nesse período houve um crescimento significativo de novas unidades além de unidades reativadas em todo o país. Muitas usinas criaram uma destilaria anexa para a produção do etanol. Minas Gerais se insere nesse contexto como uma nova área de expansão da monocultura canavieira no Brasil. Com essa expansão, a produção canavieira obteve um crescimento no país. A produção de cana-de-açúcar obteve um crescimento significativo de 2000 a 2009 passando dos 3 milhões de toneladas/ano pra mais de 6,5 milhões de toneladas/ano (PAM-IBGE, 2011).

Em 2011, o setor sucroenergético vive uma queda em sua produção de etanol devido a crise econômica de 2008 e a seca ocorrida. Com a ausência de investimentos no setor, as usinas não renovaram seus canaviais, o que deve ocorrer num período de 5 em 5 anos. Isso fez com que a produtividade diminuísse na última safra (2010/2011), sendo necessário importar etanol para suprir a demanda. De acordo com o Sindicato da Indústria de Fabricação do Álcool no Estado de Minas Gerais - SIAMIG, o desafio do setor é manter o etanol como uma fonte energética competitiva frente às demais existentes. Com o desenvolvimento tecnológico, as empresas estão produzindo além do 
Expansão canavieira e impactos sócio-espaciais da produçãoo de 94 agrocombustível no Triângulo Mineiro (1980-2012), pp. 80-110.

já tradicional açúcar e álcool, energia e plástico utilizando os subprodutos da cana (caldo, bagaço e palha).

\section{A expansão da agroindústria canavieira em Minas Gerais}

A partir da década de 1970, com a utilização do álcool como combustível alternativo, houve uma necessidade de expandir as áreas de cultivo da cana no Brasil. Diante do histórico da expansão canavieira para o Centro-Sul, o objetivo desse item é explicar os principais fatores que fizeram com que Minas Gerais inserisse nesse processo. Alguns aspectos importantes como as condições favoráveis de clima e solo da região contribuíram para o aumento do cultivo da cana. Com a Revolução Verde na década de 1970, teve início o processo de ocupação das áreas de cerrado na região do Triângulo Mineiro/Alto Paranaíba. A produção de cana-de-açúcar ainda não era tão expressiva no estado de Minas Gerais como em São Paulo e posteriormente no Paraná. Nessa época surgiram as primeiras unidades no estado.

Segundo dados da União da Agroindústria Canavieira de São Paulo - UNICA, a produção de cana-de-açúcar aumentou na região Centro-Sul e diminuiu na região Nordeste na década de 1990. Foi nesse mesmo período que Minas Gerais alcançou um crescimento na produção da cana, principalmente, nas Mesorregiões do Triângulo Mineiro/Alto Paranaíba e Sul/ Sudoeste de Minas.

O setor sucroenergético de Minas Gerais tem recebido inúmeros investimentos de diversas regiões do país, acelerando sua expansão nos últimos anos. Minas Gerais tornou-se o segundo estado maior produtor de cana-de-açúcar do país, ultrapassando o Paraná, ficando atrás apenas de São Paulo ${ }^{1}$. A moagem de cana no estado atingiu até a primeira quinzena de fevereiro de 2010 mais de 50 milhões de toneladas, mostrando um crescimento de $18 \%$ em relação à produção da safra de 2008/2009. A previsão para a safra 2011/2012 é de 51 milhões e meio de toneladas (SIAMIG, 2011). O pequeno aumento em relação às safras passadas é devido à seca que ocasionou essa baixa produtividade. A previsão da safra antes da seca era de 58 milhões de toneladas.

\footnotetext{
${ }^{1}$ Dados do Sindicato da Indústria do Açúcar e do Álcool de Minas Gerais - SIAMIG.
} 


\section{Mapa 1: Minas Gerais - Unidades Sucroenergéticas instaladas e projetadas (2012)}

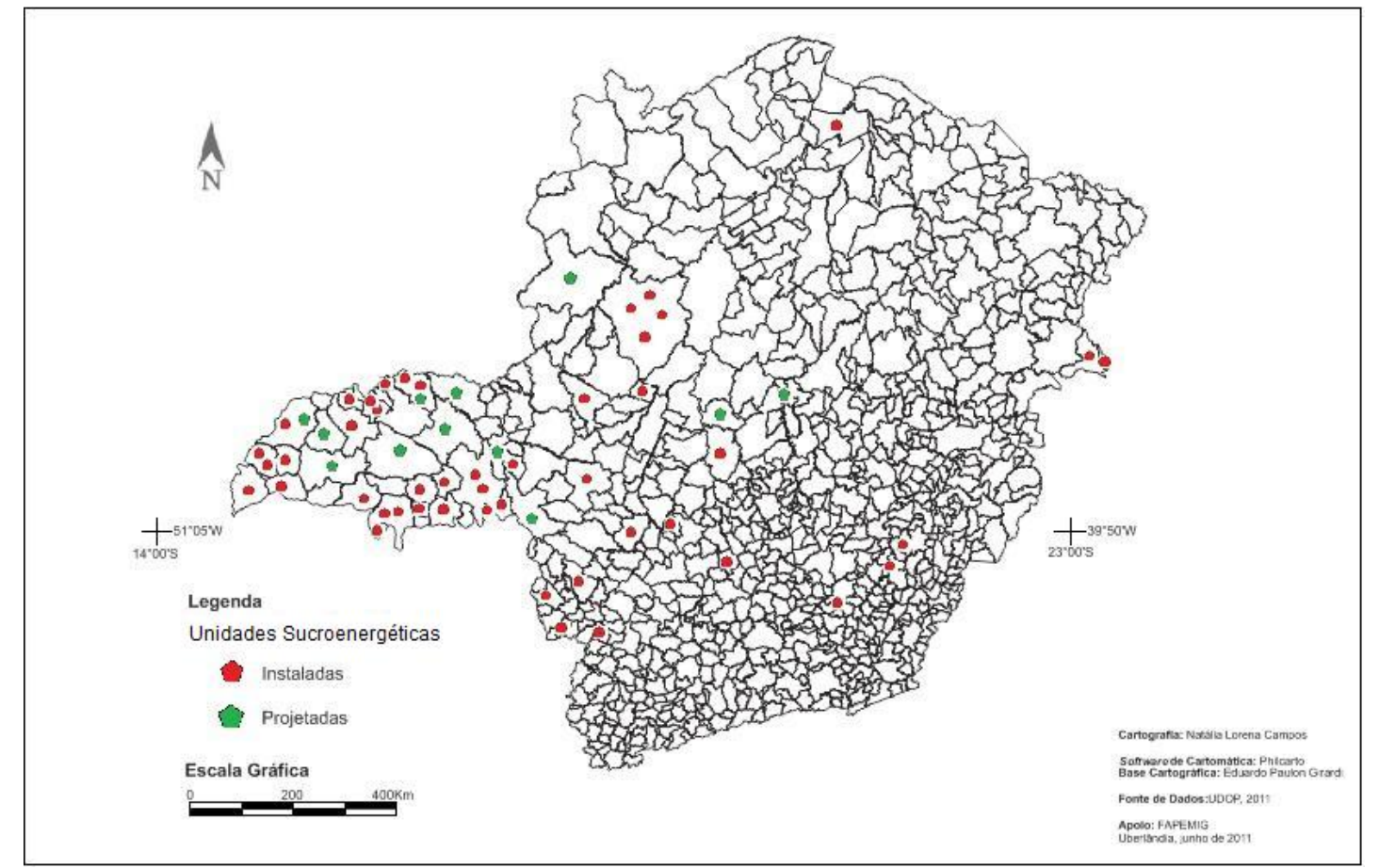

Fonte: UDOP, 2012.

Org.: CAMPOS, N. L., 2012.

O processo de expansão das agroindústrias canavieiras na mesorregião do Triângulo Mineiro/Alto Paranaíba, assim como em Minas Gerais é considerado recente frente às demais regiões do país em que a cana-de-açúcar é cultivada. Esse processo teve um rápido desenvolvimento a partir da década de 2000, período em que houve grandes incentivos à produção de etanol no estado, e estudos delimitando as áreas com maior aptidão à produção, o caso do Zoneamento Ecológico Econômico de Minas Gerais. Ao todo, o estado possui 59 unidades, sendo essas 46 instaladas e 13 projetadas, como demonstrado no mapa 1.

O Triângulo Mineiro/Alto Paranaíba se destaca das demais regiões do estado devido aos aspectos econômicos - maior proximidade com os principais centros econômicos do país; ambientais - solo propício para a produção, com pouca declividade, o que permite a inserção de máquinas no processo produtivo e condições climáticas favoráveis a cultura. Ainda lidera a produção canavieira estadual. Além das condições climáticas favoráveis é uma região estratégica por sua localização próxima dos grandes centros do país como São Paulo, Belo Horizonte e Brasília. São 38 usinas no Triângulo Mineiro/Alto Paranaíba, sendo essas 27 instaladas e 11 projetadas.

Devido aos incentivos do uso do etanol como combustível e a instalação de usinas, o número das mesmas no Triângulo teve um aumento considerável. Na década 
de 1980 instalaram-se cinco unidades. Em 1980 o número de usinas não era tão expressivo como atualmente e a inserção do etanol como combustível estava em fase inicial. A década de 1990 se apresentou pouco expressiva no cenário das agroindústrias canavieiras com a instalação de mais duas unidades.

A partir da década de 2000 houve a instalação de outras 20 unidades na mesorregião, totalizando as 27 que estão em operação até o presente momento. Isso ganhou notoriedade no momento em que as discussões ambientais ganharam destaque no cenário mundial, onde são propostas formas de se pensar em alternativas energéticas menos prejudiciais ao meio ambiente. Comparado a gasolina, o etanol emite $89 \%$ menos $\mathrm{CO}_{2}$, sendo considerado uma opção mais viável, além de não derivar de um subproduto esgotável como o petróleo.

\section{Impactos da expansão da monocultura canavieira na agricultura e pecuária de Minas Gerais}

Diante do processo de expansão das lavouras de cana-de-açúcar, surgiram questões em relação aos impactos que essa monocultura gera no aspecto social, econômico e ambiental. A partir da modernização produtiva da agricultura e com os incentivos do estado surgiram às primeiras unidades de produção em Minas Gerais. Como aponta Pessôa (1982), essa modernização da agricultura trouxe apenas desenvolvimento econômico, mas não desenvolvimento rural, pois está pautada no aumento de produção e produtividade.

[...] a modernização da agricultura não conduz, necessariamente, ao desenvolvimento rural e sim ao desenvolvimento econômico, porque está diretamente interessada no aumento da produção e produtividade; não leva em conta o homem, elemento importante nesta transformação e em todo processo de desenvolvimento também, pois as condições sócio-econômicas das pessoas que participam diretamente no processo de produção constituem preocupações do desenvolvimento rural (PESSÔA, 1982, p. 20).

A partir dessa discussão, temos as implicações que o agronegócio gera no campesinato a partir da intensificação da monocultura canavieira e seu modo de produção, que necessita de áreas cada vez maiores para o seu desenvolvimento. Minas Gerais se inseriu nesse contexto por possuir áreas extensas a essa produção, além de condições climáticas e os tipos de solo favoráveis que contribuíram para essa expansão. 
Com isso, teve início o processo de ocupação das áreas de cerrados na região do Triângulo Mineiro/Alto Paranaíba.

Com o surgimento dos automóveis bicombustíveis (flexfuel), e os constantes aumentos no preço da gasolina a partir da década de 2000, o número de unidades produtivas teve um significativo aumento em todo o país, assim como na região estudada e a tendência é a implantação de mais unidades e extensão das lavouras de cana em todo o estado. A expansão canavieira tem aumentado de forma acelerada nos últimos anos, incorporando novas áreas de cultivo. Isso reflete nas discussões a respeito da ameaça à produção de alimentos onde sua área cultivada está diminuindo devido o desenvolvimento de empresas do agronegócio. No que diz respeito a produção agrícola da região, milho, soja, entre outros, a área plantada das lavouras de cana-de-açúcar obteve grande salto frente as outras culturas, que se mantiveram estáveis ou diminuíram suas áreas de cultivo, e grande participação econômica segundo o IBGE.

O que ocorre é uma "tendência de diminuição das variedades produzidas, com o avanço e predomínio das monoculturas ligadas ao agronegócio" (Diagnóstico de Impactos de grandes Projetos em Direitos Humanos, 2009, p.61). Esses dados podem ser observados na tabela 1, que traz a variação da área plantada das principais culturas da região, destacando a cana com o maior saldo positivo frente as demais e o arroz com expressiva redução em sua área plantada.

Tabela 1 - Variação da área plantada (\%) de cultivos selecionados na Mesorregião do Triângulo Mineiro/Alto Paranaíba (2007-2009)

\begin{tabular}{|c|c|c|c|c|c|}
\hline \multirow[b]{2}{*}{ Culturas } & \multicolumn{2}{|c|}{2007} & \multicolumn{2}{|c|}{2009} & \multirow{2}{*}{$\begin{array}{l}\text { Variação da } \\
\text { área plantada } \\
2007-2009 \\
(\mathrm{em} \%)\end{array}$} \\
\hline & $\begin{array}{l}\text { Área plantada } \\
\text { (em ha) }\end{array}$ & $\begin{array}{l}\text { Área plantada } \\
\text { (em \%) }\end{array}$ & $\begin{array}{l}\text { Área plantada } \\
\text { (em ha) }\end{array}$ & $\begin{array}{l}\text { Área plantada } \\
\quad(\mathrm{em} \%)\end{array}$ & \\
\hline Cana-de-açúcar & 290.237 & 21,72 & 467.258 & 30,78 & 60,99 \\
\hline Soja & 544.254 & 40,73 & 556.195 & 36,64 & 2,19 \\
\hline Milho & 401.719 & 30,06 & 377.816 & 24,89 & $-5,95$ \\
\hline Sorgo & 42.480 & 3,17 & 57.726 & 3,8 & 35,88 \\
\hline Algodão & 10.992 & 0,82 & 3.213 & 0,21 & $-70,76$ \\
\hline Feijão & 35.562 & 2,66 & 50.233 & 3,3 & 41,25 \\
\hline Arroz & 10.996 & 0,82 & 5.244 & 0,34 & $-52,3$ \\
\hline $\begin{array}{c}\text { Total da } \\
\text { Lavoura } \\
\text { Temporária } \\
\end{array}$ & 1.336.204 & 100 & 1.517 .685 & 100 & 13,58 \\
\hline
\end{tabular}

Fonte: PAM-IBGE, 2007 e 2009/ AFES, 2009, adaptada pela autora.

Org.: CAMPOS, N. L., 2012. 
Expansão canavieira e impactos sócio-espaciais da produçãoo de 98 agrocombustível no Triângulo Mineiro (1980-2012), pp. 80-110.

Como apontado no estudo sobre os impactos de grandes projetos em direitos humanos, a expansão da cana no cerrado pode estar ocorrendo em áreas agrícolas ou remanescentes de vegetação nativa e as regiões que estão sendo afetadas por essa expansão já apresenta grande queda na produção de alimentos, como já ocorreu no Estado de São Paulo onde a produção da cana superou a de cultivos como milho, feijão, café, arroz e laranja.

A partir da análise dos mapas referentes a área plantada com cana-de-açúcar no Triângulo Mineiro/Alto Paranaíba (Figura 1), percebemos a evolução dessa área no período de 1990 a 2009. Temos que essa evolução tende a se expandir cada vez mais em diversos municípios que antes não apresentava participação na produção canavieira.

A evolução da área plantada com cana-de-açúcar foi moderada até a década de 2000, incorporando poucos municípios nesse processo produtivo. Essa evolução moderada deve-se ao fato de a região ainda não possuir muitos empreendimentos canavieiros, que teve seu desenvolvimento após a década de 2000 como já mencionado. Com o crescente número de unidades, as áreas plantadas na mesorregião aumentaram significativamente, incorporando novos municípios na cultura da cana-de-açúcar.

Registra-se que no período de 2005 a 2009 houve um grande aumento da área plantada, principalmente na área central da mesorregião, onde houve a inserção da monocultura em municípios que até então não haviam lavouras de cana e a forte concentração em municípios onde a monocultura já era acentuada no início dos anos 1990, como Frutal, Iturama, Tupaciguara e Uberaba. Municípios como Prata e Uberlândia só entraram nesse cenário a partir de 2005. 
Figura 1: Evolução da área plantada de cana-de-açúcar no Triângulo Mineiro/Alto Paranaíba (1990, 1995, 2000, 2005 e 2009) ${ }^{2}$

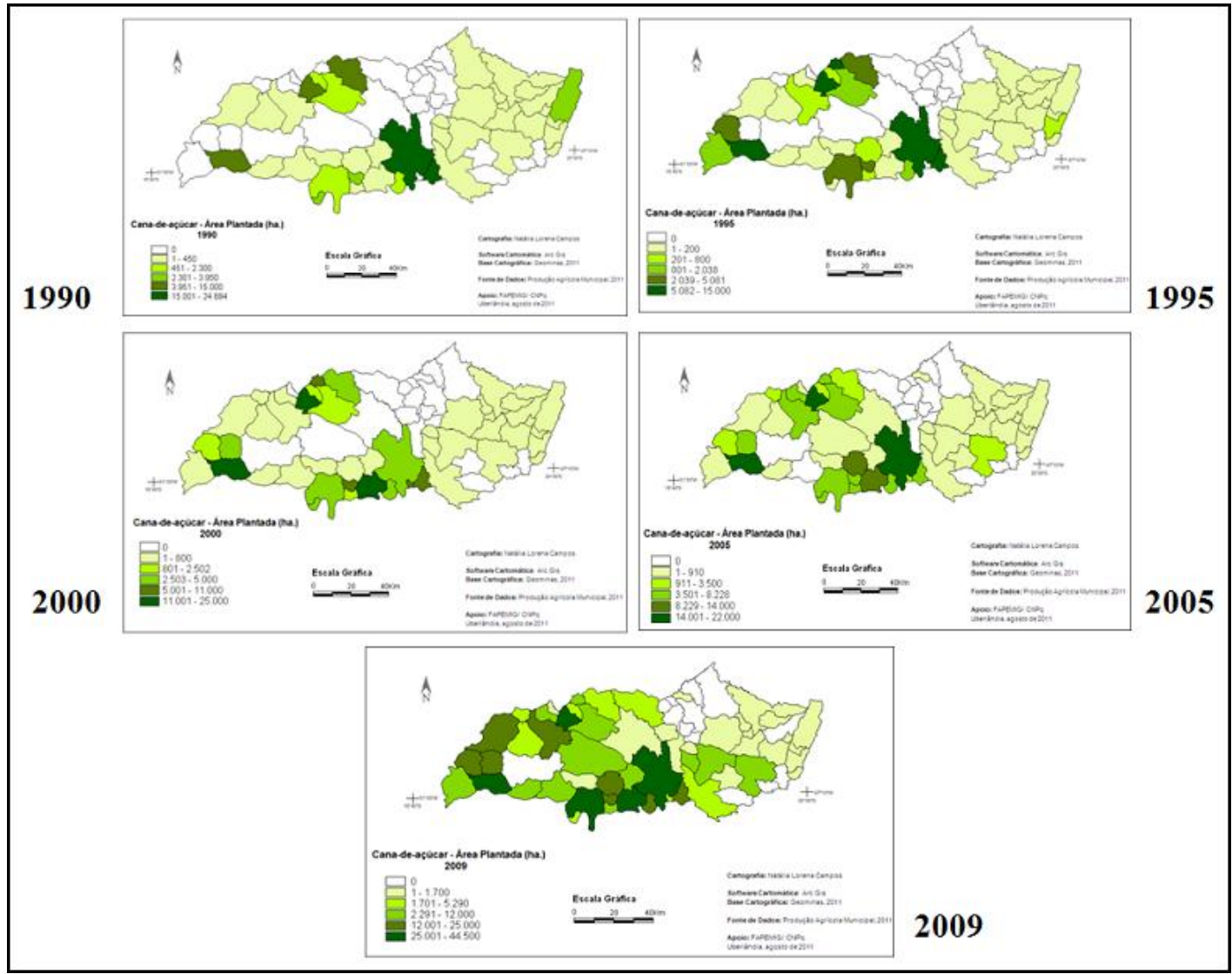

Fonte: PAM-IBGE, 2012.

Org.: CAMPOS, N. L., 2012.

A análise da produtividade é semelhante a da área plantada. A produção se acentuou na área central da mesorregião e obteve um forte crescimento nos municípios de Frutal, Iturama, Tupaciguara e Uberaba. Diversos municípios produzem cana-deaçúcar para usinas localizadas em sua proximidade, fazendo com que a área plantada e a produção se desenvolva em grande parte da mesorregião.

Nesse sentido, novas áreas passaram a participar da produção canavieira no Triângulo Mineiro/Alto Paranaíba. O município de Uberaba, conhecido tradicionalmente pela pecuária e o gado zebu, vem se destacando na produção canavieira, o que desencadeia a crítica a expansão nas áreas de pastagem. O que deve ser analisado é até que ponto a expansão das lavouras de cana pode ser notada em áreas de agriculura e de pastagem do Triângulo Mineiro/Alto Paranaíba. A região se destaca na produção de carne e leite, o que pode prejudicar a demanda dessa produção tanto em quantidade quanto no custo final do produto. Esse proceso teve início a partir da década

\footnotetext{
${ }^{2}$ Os municípios que apresentam a variável zero não possuem registro de informação sobre a área plantada, segundo os dados da Produção Agrícola Municipal, IBGE.
} 
Expansão canavieira e impactos sócio-espaciais da produçãoo de 100 agrocombustível no Triângulo Mineiro (1980-2012), pp. 80-110.

de 1990, com a substituição das áreas de pastagem por lavouras de cana-de-açúcar, e o impacto é ainda maior se analisado os municípios separadamente. No período em que se iniciou a expansão da monocultura canavieira, foi observado um decréscimo no efetivo bovino da região, assim como na área de pastagem onde o gado está requerendo menos espaço pelos confinamentos.

Tabela 2: Área de agricultura, pecuária e florestas substituídas pela cana-deaçúcar (ha.) (2007-2008)

\begin{tabular}{l|cccc|cccc}
\hline \multirow{2}{*}{ Atividades } & \multicolumn{4}{|c|}{$\mathbf{2 0 0 7}$} & \multicolumn{4}{c}{$\mathbf{2 0 0 8}$} \\
\cline { 2 - 9 } & MG & GO & MS & MT & MG & GO & MS & MT \\
\hline Agricultura & 93.883 & 59.442 & 26.823 & 15.134 & 91.959 & 108.072 & 38.908 & 17.761 \\
Pecuária & 25.656 & 25.703 & 18.395 & 8.440 & 48.284 & 34.514 & 48.465 & 10.555 \\
Florestas & 739 & 0 & 1.119 & 1.892 & 876 & 0 & 0 & 2.385 \\
\hline \multicolumn{1}{c}{ Total } & $\mathbf{1 2 0 . 3 0 6}$ & $\mathbf{8 5 . 5 5 9}$ & $\mathbf{4 6 . 4 4 6}$ & $\mathbf{2 5 . 5 2 4}$ & $\mathbf{1 4 1 . 1 9 0}$ & $\mathbf{1 4 3 . 2 5 5}$ & $\mathbf{8 7 . 4 3 4}$ & $\mathbf{3 0 . 7 3 5}$ \\
\hline
\end{tabular}

Fonte: CANAST-INPE, 2007-2008

Org.: CAMPOS, N. L., 2012.

A tabela 2 mostra como a cana-de-açúcar vem incorporando novas áreas para o seu cultivo. A área correspondente a pecuária em Minas Gerais dobrou de 2007 para 2008 e no Mato Grosso do Sul o aumento foi ainda maior. Em relação a agricultura, o estado de Goiás é o que apresenta maior impacto, tendo quase 50\% de sua área substituída pela expansão canavieira.

\section{Impactos da monocultura canavieira sobre o trabalho}

Além das implicações do modo de produção dos agrocombustíveis com a agricultura e a pecuária, ela causa impactos nos trabalhadores, onde se sujeitam a um trabalho degradante e exaustivo que subordina o trabalhador a uma forma de vida precária. Os trabalhadores da cana-de-açúcar, em sua maioria, são constituídos de migrantes, que saem do seu local de origem de maneira esporádica para trabalhar nas lavouras.

Essa demanda populacional nos municípios canavieiros faz com que o poder local e demais instituições públicas tenham que lidar com um número maior de equipamentos sociais e serviços públicos nas áreas da saúde, educação, habitação, segurança, saneamento básico entre outros e geralmente elas não tem aumento de recursos públicos para lhe dar com essa situação. A presença dos migrantes modifica o modo de vida da população desses municípios. Em relação a moradia, muitos dividem "residências coletivas" com cerca de 30 homens em uma residência que comportaria no máximo seis pessoas, de acordo com o Diagnóstico de Impactos de Grandes Projetos 
em Direitos Humanos (2009). Essa situação prejudica a saúde dos trabalhadores que fica comprometida devido a falta de higiene local.

A região do Triângulo Mineiro/Alto Paranaíba recebe trabalhadores principalmente da região Nordeste do país e do Vale do Jequitinhonha em Minas Gerais. Os trabalhadores que em sua maioria são provenientes dessas regiões do páis, geralmente são ou já foram camponeses praticantes de agricultura de subsistência em pequenas áreas rurais. Eles encontram nos canaviais uma forma de complementação de renda para o sustento de suas famílias.

Os trabalhadores do corte da cana estão cada vez mais dependentes desse emprego precário e temporário. Muitos trabalham na lavoura por não terem outra oportunidade e recebem salários muito baixo, além de possuir despesas como aluguel, alimentação, sobrando pouco para a sobrevivência. Essa exploração da mão-de-obra é recorrente, assim como a falta de assistência médica. Muitos trabalhadores morrem de exaustão ou em acidente de trabalho sem receber assistência, além de inalar agrotóxicos e a cinza oriunda da queima da cana. Uma forma que algumas usinas encontraram para evitar que os trabalhadores morressem de exaustão foi a distribuição de estimulantes com sais minerais. Essa medida só faz com que esses trabalhadores tenham um melhor condicionamento físico, não solucionando os principais problemas vividos no corte da cana.

Esse trabalho, ainda que precário, se faz necessário na vida de muitas pessoas que não encontram outras oportunidades e se deparam sempre com essa realidade. A maioria desses trabalhadores são jovens, com menos de 45 anos de idade e homens que tem que suportar a dura rotina do trabalho, que em sua maioria encontra-se no corte da cana.

Essa questão da precariedade no trabalho não é diferente em Minas Gerais. No início do processo de expansão canavieira na década de 1980, o trabalho nos canaviais era visto como uma oportunidade de ganhar dinheiro. De acordo com o Presidente do Sindicato dos Trabalhadores Rurais e Agricultores Familiares de Centralina e Araporã, a instalação de uma usina fazia com que muita gente se deslocasse para trabalhar nelas, e hoje (após a crise de 2008) o setor parou. 


\begin{abstract}
Quando chegou a cana... chegou a coisa do futuro pra se ganhar dinheiro, chegou pra assim tudo. Então todo mundo começou a... No início, pro cê tê uma noção, pessoas jovens que tava estudando foi trabalha na cana é... crianças [...] Tudo foi maravilhoso nos anos oitenta, mas a partir daí eu creio que hoje (eu já vou pular pros dias de hoje) nós tamo é com problema, o setor tá... parô de ganhá milhões de dinheiro, e os trabalhadores tão aí a deus-dará ${ }^{3}$ (ALMEIDA; MORAIS; RESENDE, 2009, p. 214).
\end{abstract}

O que mais preocupa os trabalhadores das lavouras canavieiras é a mecanização das colheitas que pretende atingir 100\% da área plantada no estado até o ano de 2014, de acordo com a Deliberação Normativa COPAM no 133/09. Com isso, muitos poderão ficar sem emprego. Segundo Mendonça (2009) “a expansão e a crescente mecanização no setor canavieiro têm gerado maior exploração da força de trabalho, através de formas precárias de arregimentação, contratação, moradia e alimentação". Com a mecanização, o trabalhador está sujeito a necessidade de exercer mais sua força de trabalho para competir com os índices de produção das máquinas.

Como forma de minimizar os problemas sociais decorrentes da mecanização, foi criado pela Federação dos Trabalhadores na Agricultura do Estado de Minas Gerais FETAEMG, o Plano Nacional de Qualificação do Setor Sucroalcooleiro financiado com recursos do Fundo de Amparo ao Trabalhador, a fim de preparar 25 mil trabalhadores para serem recolocados no setor. Os trabalhadores que participarão do curso serão indicados pelas empresas. Em Minas Gerais, 43 empresas aderiram o curso de qualificação, sendo 66\% delas localizadas no Triângulo Mineiro/Alto Paranaíba Campo Florido, Conceição das Alagoas, Fronteira, Frutal, Itapagipe, Iturama, João Pinheiro, Monte Belo, Pompéu, Santa Juliana e Serra dos Aimorés.

O projeto, apesar de sua importância, não resolverá todo o problema. Para isso, cabe ao governo criar vagas em outros setores para absorver essa mão-de-obra desempregada, e em relação aos migrantes, incentivar os municípios de origem a criar postos de trabalho para que esse pessoal não necessite sair de seu local de origem para complementar sua renda na busca do sustento de suas famílias.

\footnotetext{
3 Entrevista com Eurípedes Batista Ferreira, Presidente do Sindicato dos Trabalhadores Rurais e Agricultores Familiares de Centralina e Araporã, In: História \& Perspectivas, 2009, p. 214.
} 


\section{Impactos da produção canavieira sobre a produção rural familiar e camponesa e nos assentamentos rurais do Triângulo Mineiro/Alto Paranaíba}

Outro problema da expansão da cana e a produção dos agrocombustíveis é que essas lavouras canavieiras não atingem apenas áreas de grandes produtores agrícolas. Tem-se que essa expansão está atingindo áreas destinadas à produção camponesa. A expansão em Minas Gerais fez ressurgir inquietações que ultrapassam as problemáticas discutidas ao longo do desenvolvimento desse trabalho, tais como os impactos da produção de etanol sobre o cultivo de alimentos, uma vez que a monocultura consiste numa ameaça potencial à produção familiar, no caso, aos assentamentos de reforma agrária. Minas Gerais é o estado da Região Sudeste onde mais se concentram assentamentos rurais. Os assentamentos, em sua maioria, são frutos de ocupações de terras realizadas por movimentos sociais.

As ocupações sempre foram responsáveis pelo aumento do número de assentamentos implantados. A maior parte dos assentamentos rurais é fruto das ocupações de terra. Com a diminuição das ocupações, também diminuiu o número de assentamentos, por essa razão o governo teve que maquiar os números de 2001, como a Folha de São Paulo denunciou amplamente. (FERNANDES, 2001, s/p).

Isso ocorre devido às pressões realizadas pelos movimentos para obter a desapropriação das terras a fim de Reforma Agrária. Após a conquista da terra a luta não termina. Falta apoio político e infraestrutura nos assentamentos e ainda há conflitos e perseguições entre assentados e latifundiários. Além dessas questões, alguns assentados estão tendo que lutar contra o modelo produtivo do agronegócio.

De acordo com a pesquisa realizada por Souza (2010) sobre a dinâmcia agroindustrial no município de Campo Florido-MG, observou-se que tem ocorrido a adoção do arrendamento de lotes no PA Nova Santo Inácio Ranchinho devido à chegada da Usina Coruripe no município. Nesse local é possível visualizar o processo de territorialização do capital sucroalcooleiro envolvendo áreas de pequena produção. A produção de cana, por meio do arrendamento dos lotes, pode garantir remuneração suficiente para assegurar o sustento das famílias no assentamento. Entre os fatores que contribuíram para a configuração deste quadro no assentamento, destacam-se as dificuldades de acesso ao crédito e a ausência de políticas públicas adequadas à reforma agrária, capazes de impulsionar a geração de renda para a agricultura familiar. Mesmo sendo permitido o arrendamento dos lotes para o plantio da cana, algumas famílias 
Expansão canavieira e impactos sócio-espaciais da produçãoo de 104 agrocombustível no Triângulo Mineiro (1980-2012), pp. 80-110.

ainda tentam resistir à implantação desta cultura, permanecendo com as atividades relacionadas à pecuária para a produção leiteira.

Além de grande produtor de cana-de-açúcar, o Brasil também possui destaque nas produções de laranja, milho, soja, café, e trigo. Essas produções se dão principalmente para a exportação, o que faz com que a economia do país se desenvolva possitivamente. Esse modelo agroexportador ao qual o Brasil está inserido faz com que o mesmo ganhe destaque em sua produção, movimente a economia do país além de gerar grandes lucros. Aliás, isto constrói a representação de modernidade e sustentabilidade, deixando de lado os impactos negativos que esse modelo gera sobre a natureza e as condições de trabalho.

Mas, o que não podemos deixar de questionar é até que ponto essas extensas monoculturas afetam as pequenas produções, como a agricultura familiar, que já é comprovada a principal fornecedora de alimentos à mesa dos brasileiros.

Além disso, embora o etanol como combustível seja considerado uma fonte de energia limpa, menos prejudicial ao meio ambiente, o seu modo de produção traz inúmeras implicações em relação às questões ambientais além de expulsar os trabalhadores do campo e ameaçar a produção de alimentos. Segundo Fabrini (2010), o processo de modernização da agricultura e a incorporação de novas terras à dinâmica capitalista provocaram a expulsão de milhares de pequenos proprietários, rendeiros, ribeirinhos, caiçaras, posseiros, quilombolas, dentre outros camponeses, e indígenas de suas terras.

O pequeno produtor está cada vez mais cercado pela cana e muitos deles optam em arrendar as suas terras para essa monocultura. Segundo o presidente do Sindicato dos Trabalhadores Rurais e Agricultores Familiares de Centralina e Araporã, 89\% das terras na região desses municípios é arrendada. A própria usina possui pouca lavoura e arrendam terras num período de dez anos, no qual ela é responsável pelo plantio da cana. Nesses municípios não existem mais pequenos produtores. $\mathrm{O}$ pequeno produtor está na cidade e sua terra arrendada pra usina. 
[...] hoje nós não temo pequeno mais. O pequeno tá aqui na cidade, ele tá... tá aposentado (aposentou) e ficô só na praça... e alugô a terra dele, e tá só na praça... pescando, não tão fazendo nada. Então, a usina monopolizou. Ela é dona de tudo praticamente... é a prefeita, delegada, juiza do município... ${ }^{4}$ (ALMEIDA; MORAIS; RESENDE, 2009, p. 216).

Os pequenos produtores sofrem pressão diante da instalação de uma usina, e acabam se submetendo a vender ou arrendar suas terras por não conseguir produzir. Segundo o estudo, os agricultores familiares do PA Água Vermelha em Iturama ficaram ilhados pelas plantações de cana. A gravidade do problema fez com que ao agricultores do assentamento passassem a utilizar agrotóxicos para proteger suas plantações devido as pragas que migravam das plantações de cana (Diagnóstico de Impactos de Grandes projetos em direitos humanos, 2009, p. 74). Isso fez com que o preço da produção aumentasse, consequentemente aumentando o valor final do produto comercializado.

Essas discussões nos levam a uma série de qustões que implicam em até que ponto o desenvolvimento do agronegócio, no caso as agroindústrias e investimento energético do país possa ameaçar e gerar impactos e/ou prejuízos às outras atividades econômicas no campo, como a agricultura (familiar/camponesa) e afetando o modo de vida camponês.

\section{Considerações finais}

O agronegócio tem causado bastante discussão nos debates da questão agrária atual no que diz respeito aos impactos gerados pelas monoculturas, que necessitam cada vez mais de extensas áreas para sua produção, apropriando de territórios camponeses, promovendo a exclusão do pequeno produtor rural no desenvolvimento do capital. Nesse sentido, esse trabalho teve como principal objetivo compreender a recente expansão da monocultura canavieira no Triângulo Mineiro/Alto Paranaíba e suas implicações na produção de agrocombustíveis.

Notamos que a agricultura atual não se distingue tanto da agricultura do passado. Ambas são voltadas ao lucro e acumulação de capital, sendo a do passado para o desenvolvimento econômico das metrópoles e a atual para o desenvolvimento

\footnotetext{
4 Entrevista com Eurípedes Batista Ferreira, Presidente do Sindicato dos Trabalhadores Rurais e Agricultores Familiares de Centralina e Araporã, (História \& Perspectivas, 2009).
} 
econômico do país. Concordamos com Porto Gonçalves (2011), que a modernização tecnológica que estamos vivendo hoje, com o agronegócio e seus equipamentos modernos é um mito, pois o Brasil do século XVI já exportava produtos manufaturados como o açúcar. O país já era moderno tecnologicamente, o que distinguia era que essa tecnologia era colocada para nos explorar e, não nos servir, nos fazendo questionar essa ideologia de modernidade que vivenciamos hoje.

A vocação agrícola do Brasil fez com que ele tornasse o maior exportador do mundo de algumas espécies de cereais, grãos, frutas. Essa vocação já existia, e sempre voltada aos interesses do capital. O interesse que abordamos nesse trabalho é em relação ao desenvolvimento energético que despontou o setor canavieiro nesse processo.

O uso do etanol como combustível surgiu como uma opção de nova fonte energética para superar as crises em relação ao petróleo e os constantes aumentos do preço do barril. Consideramos que a produção do etanol a partir da cana-de-açúcar se mostrou mais vantajoso econômico e ambientalmente, fazendo com que o Brasil despontasse como pioneiro nessa produção. Nesse sentido, buscamos demonstrar como o agronegócio canavieiro vem se desenvolvendo no país e criando novos produtos além do etanol.

A partir da década de1930 que se iniciou a criação das políticas públicas e houve uma maior preocupação com a produção canavieira, com a criação do IAA (1933) que foi importante como órgão controlador do mercado de açúcar e incentivando a produção do anidro no país. Por volta da década de 1960 e com o movimento expansionista das agroindústrias, surgiram preocupações a respeito dos impactos, problemas ambientais e a forma insustentável da produção de agrocombustíveis. O Proálcool foi a política pública em nível nacional mais importante para o setor, no início da década de 1970, que em sua primeira fase objetivou a produção de álcool para ser adicionada à gasolina e a segunda fase caracterizada pela produção de álcool como combustível, utilizado nos veículos movidos exclusivamente a álcool hidratado. O programa, embora visto como bem sucedido, gerou inúmeras críticas no que diz respeito ao aumento da área de cultivo da cana-de-açúcar, enquanto a de alimentos se manteve inalterada, despertando as críticas devido aos problemas sociais gerados no campo.

De acordo com as diferentes visões, o Proálcool só teria sucesso e seria viável se compatível com uma política energética global e com uma política agrária e agrícola que considerasse todas as conseqüências do crescimento desse programa. Os problemas 
em relação ao modelo de produção do agronegócio é que instigaram o objetivo principal desse trabalho, que analisou os impactos da produção canavieira na mesorregião do Triângulo Mineiro/Alto Paranaíba (MG).

Em relação a expansão canavieira em Minas Gerais, buscamos mostrar como ela transforma o território e impacta no modo de vida camponês e a reforma agrária. Destacamos as condições dos trabalhadores nas lavouras de cana, que muitas vezes são camponeses e se submetem a esse tipo de trabalho por ser uma vítima do modelo capitalista imposto à sociedade e que mesmo precarizado é uma forma de trabalho do qual dele muitos são dependentes, seja para o sustento das famílias, seja como complementação de renda. Assim, a análise do avanço do agronegócio nos permitiu constatar a sua influencia nas condições políticas, econômicas e sociais do país, além de criar uma gama de situações a serem estudadas devido a sua expansão.

Diante do processo de compreensão do modelo do agronegócio no Brasil, passamos por diversos aspectos que em sua maioria consideramos prejudicial para as pessoas ligadas ao campo, seja o camponês ou o agricultor familiar. A inserção de monoculturas, como a da cana-de-açúcar, vem prejudicando a produção rural familiar e camponesa que está perdendo espaço, perdendo o seu território (desterritorializando), além de ter que se submeter a esse modelo agrícola voltado a geração de lucro e acumulação de capital, por não conseguir competir com um oponente forte como o agronegócio.

Assim, surge a preocupação em relação à produção de alimentos, que em algumas áreas tem diminuído tanto em extensão quanto em sua variedade. As microrregiões de Frutal, Ituiutaba e Uberaba possuem municípios onde a cana-de-açúcar já representa entre $60 \%$ e $90 \%$ da área plantada, comparando a outras agriculturas e a pecuária. O modelo do agronegócio traz enormes prejuízos não só para os trabalhadores rurais, mas para toda a sociedade brasileira. A incorporação de terras para a monocultura canavieira já está sendo observada no Triângulo Mineiro/Alto Paranaíba, e é um dos principais problemas dos conflitos sociais em Minas Gerais.

A mesorregião do Triângulo Mineiro/Alto Paranaíba encontra-se na área de Cerrado e é tradicionalmente marcada pela pecuária e mais recentemente, pela cultura de grãos. A "modernização" da agricultura foi a incentivadora na consolidação do agronegócio nos Cerrados, transformando-o em um espaço da expansão da fronteira agrícola. Com isso, a agricultura na região se reestruturou como agronegócio em detrimento das outras formas de cultivares, como a agricultura familiar. 
Expansão canavieira e impactos sócio-espaciais da produçãoo de 108 agrocombustível no Triângulo Mineiro (1980-2012), pp. 80-110.

Vimos diferentes tipos de impactos relacionados à expansão canavieira no Triângulo Mineiro/Alto Paranaíba, impactos relacionados aos assentamentos rurais, a agricultura familiar, ao campesinato, ao trabalho, dentre outros. O êxodo rural também se configura como vítima da expansão canavieira na região, onde os produtores rurais se deslocaram para a cidade ou para outras regiões, por não conseguirem se manter no campo, devido aos embates com a produção canavieira e as dificuldades de produzir em suas terras.

Devemos considerar que esse desenvolvimento energético gerou desenvolvimento econômico e lucro ao país. O problema é que esse desenvolvimento não levou em consideração o desenvolvimento social, e não podemos deixar de questionar até que ponto esse desenvolvimento econômico é positivo, tendo que esse lucro venha a ser necessário ser utilizado na exportação de alimentos, uma vez que o país opte pelo modelo do agronegócio, o que é inadmissível a um país com grande vocação agrícola.

\section{Referências}

AFES. Ação Franciscana de Ecologia e Solidariedade. Diagnóstico de Impactos de grandes projetos em direitos humanos - Estudo de caso sobre a cana-deaçúcar (agronegócio/agroecologia) no Triângulo Mineiro e Alto Paranaíba, Minas Gerais. Coordenador: Frei Rodrigo de Castro Amedée Péret. Uberlândia, 2009.

ALCÂNTARA FILHO, J. B., SILVA, J. G. Uma alternativa não concentradora para o Proálcool: a pequena unidade de produção e a micro-destilaria. Abra. Campinas, v. 11, n. 1, p. 37-44, 1981.

BRAY, S. C. As políticas da agroindústria canavieira e o PROÁLCOOL no Brasil/ Sílvio Carlos Bray, Enéas Rente Ferreira e Davi Guilherme Gaspar Ruas. Marília: Unesp-Marília-Publicações, 2000.

CLEPS JUNIOR, J. Dinâmica e estratégias do setor agroindustrial no cerrado: o caso do Triângulo Mineiro. 1998. 291 f. Tese (Doutorado em Organização do Espaço) - Instituto de Geociências e Ciências Exatas, UNESP/Rio Claro, 1998.

FABRINI, J. E. O campesinato frente à expansão do agronegócio e do agrocombustível. In: SAQUET, M. A., SANTOS, R. A. (Orgs.) Geografia Agrária, território e desenvolvimento. $1^{a}$ Ed. São Paulo: Expressão Popular, 2010, p. 55-88.

FERNANDES, B. M. Questão Agrária: conflitualidade e desenvolvimento territorial. Disponível em: <www.geografia.fflch.usp.br>. 
FURTADO, C. Formação econômica do Brasil. Rio de Janeiro: Fundo de Cultura, 1963.

GOMES, R. M.; CLEPS JUNIR, J. Transformações no mundo rural e a reforma agrária em Minas Gerais: os movimentos socioterritoriais e a organização camponesa no Triângulo Mineiro. In: Feitosa, A. M. A.; Zuba, J. A. G.; Cleps Junior, J. (Orgs.). Debaixo da lona: Tendências e desafios regionais da luta pela posse da terra e da reforma agrária no Brasil. Goiânia: Editora da UCG, 2006, p. 131-169.

HESPANHOL, A. N. Modernização da agricultura e desenvolvimento territorial. In: $4^{\circ}$ Encontro Nacional de Grupos de Pesquisa, 2008, São Paulo. Anais... São Paulo: USP, p. 370-392.

MENDONÇA, M. L. O monopólio da terra e a produção de agrocombustíveis. Caros Amigos, abril, p. 20-22. 2010.

MULLER, G. Complexo agroindustrial e modernização agrária. São Paulo:

HUCITEC, 1989. 149 p.

OLIVEIRA, A. U. A Agricultura camponesa no Brasil. São Paulo: Contexto, 1996.

PEREIRA, G. T. V. O setor alcooleiro: da rígida intervenção ao processo de regulamentação. 2007. 85 f. Monografia. Departamento de Ciências econômicas, UFSC/ Florianópolis, 2007.

PESSÔA, V. L. S. Características da modernização da agricultura e do desenvolvimento rural em Uberlândia. 1982. 161 f. Dissertação (Mestrado em Organização do Espaço) - Instituto de Geociências e Ciências Exatas, UNESP /Rio Claro, 1982.

PORTO-GONÇALVES, C. W. Os índios nunca foram atrasados, eles sempre viveram seu próprio tempo. BRASIL DE FATO. 24 a 30 nov. 2011.

RAMOS, P. Referencial teórico e analítico sobre a agropecuária brasileira. In: Pedro Ramos... [et al]. Dimensões do agronegócio brasileiro: políticas, instituições e perspectivas. Brasília: MDA, 2007,360 p. p.18-52.

RAMOS, P. A propriedade fundiária e a agroindústria canavieira no Brasil. Reforma Agrária, Campinas, v. 3, n. 3, p. 35-52, set/dez. 1991.

SANTOS. J. C. Dos Canaviais à "etanolatria": o (re) ordenamento territoral do capital e do trabalho no setor sucroalcooleiro da Microrregião Geográfica de Presidente Prudente - SP. 2009. 375 f. Tese (Doutorado em Geografia e Gestão do Território - Instituto de Geografia, UFU/ Uberlândia, 2009.

Sindicato da Indústria de Fabricação do Álcool no Estado de Minas Gerais - SIAMIG. Disponível em: <http://www.siamig.org.br/>. Acesso em: 04 abr. 2012. 
Expansão canavieira e impactos sócio-espaciais da produçãoo de 110 agrocombustível no Triângulo Mineiro (1980-2012), pp. 80-110.

UNIÃO da Indústria de cana-de-açúcar - UNICA. Disponível em: $<$ www.unica.com.br>. Acesso em 02 abr. 2012.

UNIÃO dos Produtores de Bioenergia - UDOP. Disponível em: <www.udop.com.br>. Acesso em: 02 abr. 2012.

VEIGA FILHO, A. A.; RAMOS, P. Proálcool e evidências de concentração na produção e processamento de cana-de-açúcar. Informações Econômicas, São Paulo, n. 7, p. 48-61, jul. 2006.

VIAN, C. E. F. Agroindústria canavieira: estratégias competitivas e modernização. Campinas: Átomo, 2003. 